\title{
Propagation and Production of Atlantic St. Johnswort ${ }^{1}$
}

\section{Mack Thetford and Debbie Miller ${ }^{2}$ \\ Introduction}

Atlantic St. Johnswort is a herbaceous or semi-woody plant with a decumbent growth habit, spreading from the base and forming a low mat (Bell and Taylor 1982). This plant is a candidate for beach projects requiring planting of interdunal areas and secondary dunes as well as for commercial or home landscapes. Flowers occur from June to September, are terminal and axillary, and may be solitary or in small clusters called cymules or dichasia. Each flower is 1 to $2 \mathrm{~cm}$ ( 0.39 to $0.79 \mathrm{in})$ in diameter with 5 clear yellow petals (Radford et al. 1983). Atlantic St. Johnswort occurs in sandy woods, scrub, and coastal dunes from south Florida to the Carolinas.

\section{Propagation}

It is considered easy to start ornamental selections within this genus by taking late-summer softwood cuttings from tips of current growth and rooting under high humidity or mist. Many Hypericum are also commercially micropropagated (Hartmann and others 1997). Softwood cuttings may be collected during the growing season and placed in plastic bags or stored in a cooler for transport.

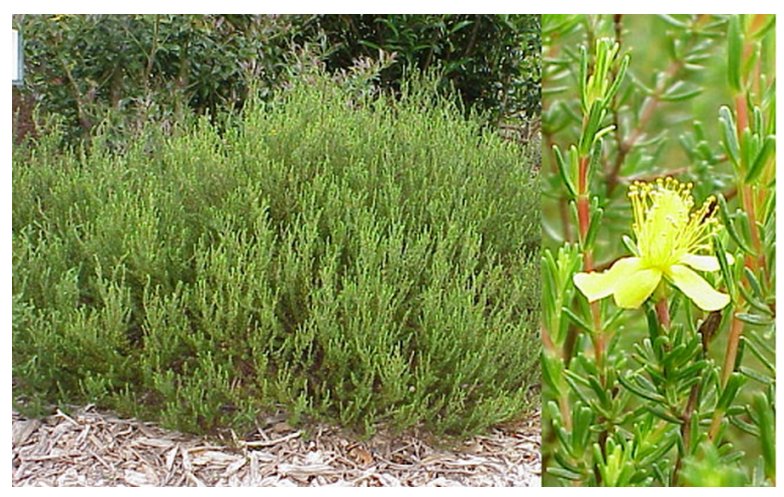

Figure 1. Atlantic St. Johnswort (Hypericum reductum) shoot and flower detail and entire plant growing in a non-irrigated Florida landscape. Credits: Photo by Mack Thetford.

Cuttings may be prepared from nonbranched terminal shoots. Cut the shoots to a length of 4 inches for uniformity and remove the foliage from the basal 1/2 inch. Treat the base of each cutting with a quick dip of an auxin solution for 1 second followed by 15 minutes of air drying, or treat with a talc-based auxin prior to insertion to a $1 / 2$ to $3 / 4$ inch depth. Cuttings may be propagated in small pots or nursery flats with inserts divided into individual cells. Well-drained propagation mixes should be used to ensure sufficient oxygen in the rooting zone. Research has shown rooting success with pinebark-based substrates or

1. This document is Fact Sheet ENH 972, from the Environmental Horticulture Department and the Wildlife Ecology and Conservation Department, Florida Cooperative Extension Service, Institute of Food and Agricultural Sciences, University of Florida. Publication date: March 25, 2004. Please visit the EDIS web site at http://edis.ifas.ufl.edu.

2. Mack Thetford, associate professor, Environmental Horticulture Department; Deborah "Debbie" L. Miller, associate professor, Wildlife Ecology and Conservation Department, Cooperative Extension Service, Institute of Food and Agricultural Sciences, West Florida Research and Education Center, University of Florida, 5988 Highway 90, Bldg. 4900, Milton, FL 32583. For more information, contact your county Cooperative Extension Service office.

The Institute of Food and Agricultural Sciences (IFAS) is an Equal Employment Opportunity - Affirmative Action Employer authorized to provide research, educational information and other services only to individuals and institutions that function without regard to race, creed, color, religion, age, disability, sex, sexual orientation, marital status, national origin, political opinions or affiliations. For information on obtaining other extension publications, contact your county Cooperative Extension Service office. Florida Cooperative Extension Service / Institute of Food and Agricultural Sciences / University of Florida / Larry R. Arrington, Interim Dean 
potting mixes containing a mixture of sphagnum peat moss, horticultural perlite and vermiculite (Thetford and Miller 2002). Cuttings should not be allowed to dry and the best method to retain moisture is the use of an intermittent mist operated daily. Cuttings may be maintained under natural photoperiod.

Research with Atlantic St. Johnswort has demonstrated that auxin application increases the number of cuttings that develop roots, and one may expect around 90\% success with auxin and 70\% success without auxin. Auxin treatment has also be shown to improve root number. Several auxin sources have demonstrated success for rooting this species and include NAA (naphthaleneacetic acid) from 500 to $1000 \mathrm{ppm}$; IBA (indole-3-butyric acid) from 1000 to 5000 ppm; and Dip'N Grow ${ }^{\circledR}$ (Dip 'N Grow Inc, Clackamas Oregon 97015-1888), a commercially available liquid formulation containing NAA and IBA at a 1:19 dilution.

Research has demonstrated successful rooting for cuttings of other Hypericum species treated with IBA-talc formulations (3000 ppm) and with liquid formulations of auxin. However, differences occurred in root numbers with IBA-alcohol solution and Dip N Grow ${ }^{\circledR}$ producing double the roots compared to the IBA-talc and control treatments. Homeowners will find many products containing these two active ingredients through their local garden centers. Products will have dilution ratios provided as part of the label recommendations. Commercial propagators and growers may choose NAA and IBA and dissolve these in isopropyl alcohol to prepare $10,000 \mathrm{ppm}$ stock solutions for further dilution with distilled water.

\section{Production}

A production schedule for this species in the spring and summer months will begin with cuttings stuck in a pinebark-based substrate such as $100 \%$ milled pine bark or a commercial planting mix. Many commercial growers will use 72-cell trays with roots initiating within 2 to 3 weeks. Rooted cuttings are removed from the mist on week 3 or 4 and the plants remain in the propagation flats through weeks 5 to 6 . Plants are irrigated as needed 2 to 3 times each week. Nutritional status of the plants is maintained by liquid fertilization ( 1 to 2 times each week) with a $150 \mathrm{ppm}$ $\mathrm{N}$ solution from products such as Peters $20 \mathrm{~N}: 10$ $\mathrm{P}_{2} \mathrm{O}_{5}: 20 \mathrm{~K}_{2} \mathrm{O}$ (JR Peters, Inc, Allentown, PA 18106). Atlantic St. Johnswort, in general, will not require pruning but may be pruned lightly in weeks 4 or 5 prior to transplant, or within 1 week after transplant to initiate additional branching. Following transplant into 4-inch or 1-quart pots, plants require an additional 4- to 6-week production period to achieve a full rootball and a canopy of approximately 6 to 8 inches.

\section{References}

Bell, CR and Taylor, BJ. 1982. Florida wild flowers and roadside plants. Laurel Hill Press. Chapel Hill. p. 79.

Hartmann, HT, Kester DE, Davies, F T Jr. and Geneve, RL. 1997. Plant propagation principles and practices. Prentice-Hall. New Jersey. pp 309, 688.

Radford AE, Ahles, HE, and Bell, CR. 1983. Manual of the vascular flora of the Carolinas. The University of North Carolina Press. Chapel Hill. 709-717.

Thetford, Mack and Debbie Miller. 2002. Propagation of 4 Florida Coastal Dune Species. Native Plants Journal. Vol.3(2):112-120. 